\title{
MISS FLORENCE BARWOOD, MBE, Honorary Companion
}

T HE DEATH of Miss Barwood came as a shock to many of the older members of the Society. She had seldom been seen since her retirement in 1962 and was missed at all the Centenary functions. Not until after the Garden Party, which she had been expected to attend, did she say that she had been ill; then, just before the Centenary Congress it was learned that she was in hospital. She was visited just before and again immediately after the Congress, so she knew that many of her friends, both at home and overseas, had asked warmly for news of her.

A number of letters have been received from members of which we publish two below-from Harald Penrose (Fellow) and R. W. Potts (Associate)--and a note from Captain Pritchard, Secretary of the Society from 1925-1951, with whom she worked for so long.

\section{Captain Pritchard writes:-}

"This far too brief a memory of Florence Barwood, who did so much for the Royal Aeronautical Society for over thirty years, is too great a task to satisfy me or many of the older members of the Society who knew her over the long period of her service.

I am very grateful that the Secretary who succeeded me fifteen years ago, wrote in July 1962, in the JouRNAL of the Society, a tribute which I would have been only too glad to have written while she was still alive.

The First World War ended in 1918. The following year, 1919, I was called out of the Royal Air Force and asked by the Royal Aeronautical Society to edit the Journal of the Society and to attend Council Meetings. In the Minutes of the Council for 1920 I noted that Florence Barwood was praised by the Council for her hard work and enthusiasm after less than two years' service as a Junior Clerk. I then knew that I had met a rather remarkable wornan (young) who knew nothing about science or mechanics, or what much of the conversation about aeronautics and aeroplanes meant. Any more than those who talked did! But she learnt faster.

That year, in and out of the Society's headquarters, were the men who had been concerned with the research, and design, and construction of fighting and bombing aircraft, who became in the years ahead some of the most famous

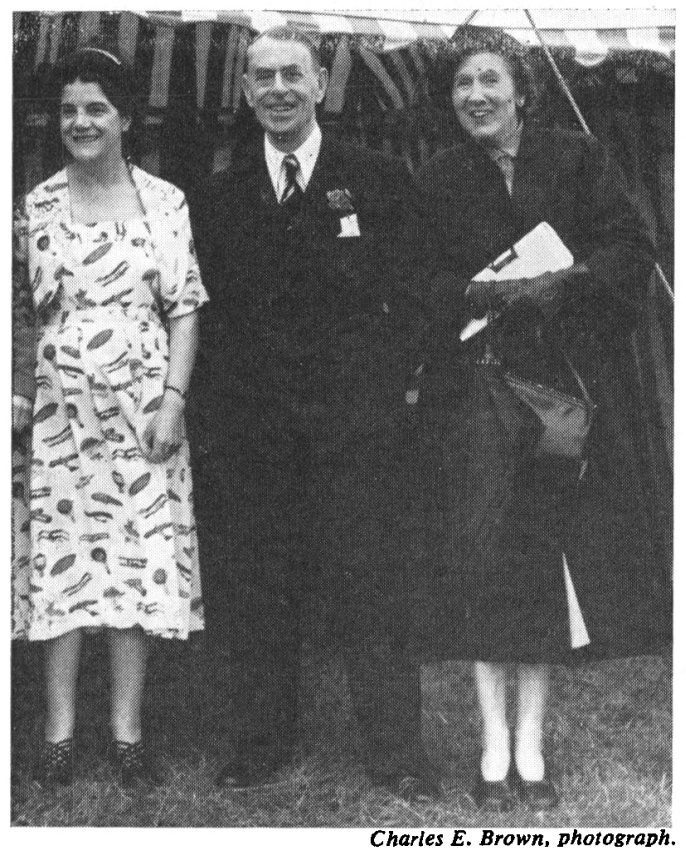

Miss Barwood with Captain and Mrs. Pritchard at the 1953 Garden Party. men in the world, of whom I can but give a brief note. Henry Tizard, whose astonishing ability and knowledge made him a leader in the air war defence and in many other things; Handley Page, who made the early great bombers and the great transport aeroplanes, Melvill Jones, Sir Sefton Brancker and the Master of Sempill and so many others. Sempill thought very much of Florence Barwood and did not hesitate to write and say so at times. All those who were concerned with the control of the Society soon found out the great store of knowledge she had upon which she could rely to give them help. Her first help was always given to new members of the Society, particularly students, and those who wished to belong to the aircraft industry. To many she gave sound advice and help.

She knew more members of the Society than any other assistant I knew and could give me more help on their outlooks and abilities than most. When she retired she left behind a list of notes about the great members who could supply me with information and knowledge of the history of the Society, which $I$ found of the greatest value and which will be used.

For many years she took down the notes at Council meetings and was responsible for many of the highly responsible reports during the war. I hope in the final writing of the history of the Society I shall have the opportunity to give many incidences of her help to make the Society what it was in her lifetime.

Many tributes were paid to her and I feel I must particularly quote from Flight International of 28th June 1962 which, after quoting from Dr. Ballantyne's appreciation added 'Thank you, Florence, and all good wishes.'

How much I appreciate those words and Florence Barwood who served me so well and the Society and all its members!"

\section{From R. W. Potts, Associate}

"I first met Miss Barwood in the days of Mr. W. Barnard Faraday, at Adam Street, Adelphi, where the Society was then; she was during those difficult days almost the Society itself, although only a young girl.

After a long interval we met again at the 50th anniversary of Wilbur Wright's first flight, and my wife and I will always remember her kindness to us then, it made our evening."

\section{From Harald Penrose, Fellow}

"I was devastated to read of the passing of Florence Barwood, and feel I must express my sorrow to you. I always regretted that she rather isolated herself from aeronautical matters after retiring, so there had been no further opportunity of meeting.

My recollection goes a long way back, to 1922 I think it was, when Florence was a quiet, very self-contained attractive looking girl, who, clad in a dark velvet dress, usually worked the slides at lectures under the eagle eye of Laurence Pritchard's Secretary, Miss St. Barbe. As a student devotee of the Library I often wondered whether I dare ask Florence to come out and have a cup of coffee with me-but instead she used to smuggle in a cup of tea for me. They were happy afternoons, and she was always very sweet and helpful. My only concern was that Laurence might descend suddenly upon me and pose a trick mathematical problem which would take me from the books.

So down the years I see the demure little girl slowly changing into the older Florence, changed but unchanged -and now the curtain. I know that there was tragedy-but I hope that at heart she found this life a happy one." 